\title{
SLC9A1 wt Allele
}

National Cancer Institute

\section{Source}

National Cancer Institute. SLC9A1 wt Allele. NCI Thesaurus. Code C118914.

Human SLC9A1 wild-type allele is located within 1p36.1-p35 and is approximately $68 \mathrm{~kb}$ in length. This allele, which encodes sodium/hydrogen exchanger 1 protein, plays a role in the regulation of cellular $\mathrm{pH}$. 